\title{
A Systematic Review of Excessive Speed Monitoring and Control System for Accident Prevention on Cameroon Highways
}

\author{
Azeh Gerald ${ }^{1,2}$, Innocent Ndoh Mbue ${ }^{1,2 *}$, Ayissi Zacharie Merlin ${ }^{1,2}$, Awa Terence Achiri ${ }^{1,2}$ \\ ${ }^{1}$ Laboratoire de Recherche Energie, Matériaux, Modélisation et Méthodes (E3M), Douala, Cameroon \\ ${ }^{2}$ Ecole National Supérieure Polytechnique de Douala (ENSPD) Université de Douala, Douala, Cameroon \\ Email: *dndoh2009@gmail.com
}

How to cite this paper: Gerald, A., Ndoh Mbue, I., Merlin, A.Z. and Achiri, A.T. (2022) A Systematic Review of Excessive Speed Monitoring and Control System for Accident Prevention on Cameroon Highways. World Journal of Engineering and Technology, 10, 28-39.

https://doi.org/10.4236/wjet.2022.101002

Received: December 19, 2021

Accepted: February 11, 2022

Published: February 14, 2022

Copyright $\odot 2022$ by author(s) and Scientific Research Publishing Inc. This work is licensed under the Creative Commons Attribution International License (CC BY 4.0).

http://creativecommons.org/licenses/by/4.0/

\begin{abstract}
Road safety is still an important issue with road accidents among the leading causes of death accounting for more than 1.2 million fatalities and 50 million injuries globally per year. Of these casualties, speeding is a substantial contributing factor. Nowadays, speed reduction is mainly achieved through speed law enforcement measures. The review is aimed at examining the different enforcement approaches used to control and monitor excessive speeds on highways at large and particularly in Cameroon. A systematic search was performed in Science Direct, Elsevier, google scholar, scientific research, and Springer, ResearchGate, Scopus, and PubMed databases. Furthermore, references of selected articles were reviewed to maximize the rate of articles found. The details of the research articles were generated using the Preferred Reporting Items for Systematic Reviews and Meta-Analysis (PRISMA) flow chart. The results show that of 658 retried articles, duplicates of 458 were excluded and 200 were screened. A total of 61 and 40 articles were screened from abstract and full pdf text respectively. Finally, 15 relevant studies were included in the study. The review revealed that the included articles on speed enforcement on the highway were limited to sanctioning defaulters for fine payments.
\end{abstract}

\section{Keywords}

Excessive Speed, Speed Enforcement, Billing and Payment, Violated Vehicle

\section{Introduction}

Motorization has enhanced the lives of many individuals and societies, but the 
benefits have come with a price. Although the number of lives lost in road accidents in high-income countries indicates a downward trend in recent decades, for most of the world's population, the burden of road traffic injury in terms of societal and economic costs is still rising substantially [1].

According to collected statistics, $93 \%$ of the world's fatalities on roads occur in low- and middle-income countries, even though these countries have approximately $60 \%$ of the world's vehicles. Road traffic injuries are the leading cause of death for children and young adults aged 5 - 29 years [2].

The causes of car accidents are mostly classified into three factors (automotive, environmental or infrastructure, and human). A major factor is due to human error (distraction, driving under the influence, drowsiness, inattention, drunkenness, speeding) [3]. Amongst these human errors, there is wide scientific evidence about the fact that speeding is the most contributing factor to risk, severity, and fatality of motor vehicle collisions [3].

Specifically, in 2004 the WHO agrees that excessive and inappropriate speed contributes to about $30 \%$ of deaths on the road in high-income countries, meanwhile in some low-income and middle-income countries speed is estimated to be the main contributory factor in about half of all road crashes. According to UNECE in 2018, speeding was a contributing factor in $26 \%$ of all traffic fatalities.

In Cameroon, most road accidents occur along with the "death triangle" (Yaoundé-Douala-Bafoussam-Yaoundé). The triangle is called the "death triangle" because it records over $46 \%$ of the entire road accidents on Cameroon highways and most of these accidents are due to excessive speed [4]. According to the elaboration of a national strategy for road accident prevention and safety in 2009 done by ministry of transport of Cameroon, it was revealed that $70 \%$ of road accidents were due to human error with excessive speed as the leading factor. The reports from 2004 to 2007 shows that excessive speed accounts for $20 \%$ of road accidents on the Yaoundé-Douala highway meanwhile reports from 2018 to 2019 along with the Douala-Dschang highway accord for 34.3\% [5] and [4]. Controlling vehicles' speed can prevent crashes occurrence and reduce the impact when they occur, lessening the severity of injuries sustained by the victims.

Developed and developing countries consider speeding as a huge problem for road safety and are conscious that controlling vehicle speed can prevent occurring crashes and reduce the impact when they do occur, lessening the severity of injuries sustained by victims. Speed humps, speed limits, and various advanced methods are used to reduce road traffic accidents by monitoring and controlling the speed of motorists within the highway.

Speed humps and bumps are the most common type of traffic calming devices due to their low cost and easy installation. They are mostly installed on risk zones like schools, markets, towns, hospitals [6]. Speed hump or bumps are raised areas of textured material on the flat section with asphalt or concrete for roadway pavement surface extending transversely across the travel way. The problem faced with this device is based on the fact that it is regulatorily only on risk zones 
meanwhile speed limits signs are implanted on dangerous zones [7].

Speed limits are also commonly used around the world to regulate the maximum speed at which motor vehicles can be operated on public roads. The speed limit signs are regulatory and are rectangular metallic material oriented vertically to communicate a set of legal maximum or minimum speeds that vehicles must travel [6]. Many motorists do not respect the road signs if some control and monitoring measures are not taken. To track violators of speed limit signs, speed cameras are used with different enforcement methods.

Generally, Road-based (mobile and fixed) and Vehicle-based are the different groups of methods used for monitoring vehicle speed on highways [8]. The general framework for monitoring and controlling the system of speeding is presented in Figure 1.

In general, a sensor for a vehicle-based type and a mobile or fixed speed gun for a road-based type are used to detect vehicle speed on the road. The vehicle speed is calculated by the sensor or snapped by a speed gun and cross-checked with a speed limit sign, if the detected speed is greater than the speed limit, then the device sends the data to a central server and a message is generated and sent to the offender manually or automatically for subsequent actions [8].

In Cameroon, speed guns are exclusively used to control vehicle speed on highways by the Ministry of Transport (MINT) and the Gendarmerie of the Ministry for Defense. Mobile and fixed speed cameras are used to sanction defaulters of speeding on different highways. Amongst the national roads in Cameroon, only N3 (Yaoundé-Douala) has a fixed-speed camera post managed by MINT.

With the mobile control system, a control agent snaps violated vehicles of a speed limit sign and informs the control team ahead through a phone call. The offender is hence interrupted for immediate payment of fines $(25,000 \mathrm{Fcfa})$. On the other hand, speed guns are fitted in chosen fixed post of N3 where defaulted vehicles of speed limit signs are snapped and stored in a built-in server. An agent of MINT periodically collects the data using a USB or a memory card and transmits it to the central service for subsequent actions.

The main problem faced today world at large and Cameroon in particular as regard speed management is the enforcement of sanction measures to violators. The manual means of enforcing sanctions has some drawbacks that must be

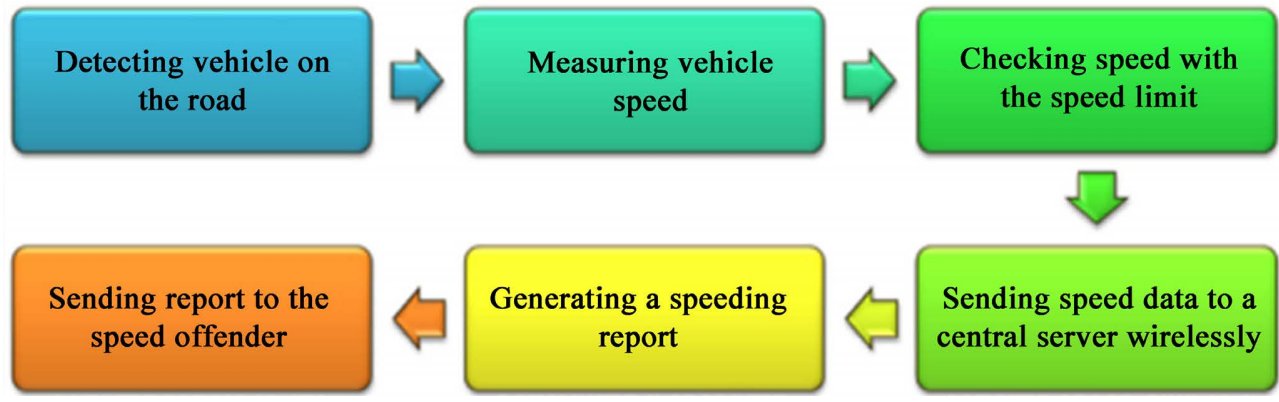

Figure 1. A general framework of vehicle speed monitoring and control system. 
dealt with to improve upon the existing enforcement systems which can go a long way to reduce or stop the disrespect of speed limits. The different drawbacks are; speeding data are collected manually for the case of fixed speed guns, sanctions to defaulters are selective through convocations for fixed control, during the mobile control, defaulters are embarrassed to pay fine instantly, the application of the enforcement is temporal, many control agents are needed at the different control post, time-consuming to road users and passengers, exposure to corruption and favoritism, the mobile system functions only during the day. To fight against these drawbacks, the review of this research work is intended to systematically identify existing gaps of existing studies on speed enforcement management and which will further clearly situate us in our innovation on the better management and implantation of speeding on Cameroon highways by not only sanctioning and billing defaulters but also automatically suspending delinquent defaulted vehicles through a web network system.

\section{Material and Method}

A systematic method of literature was done online by searching the keywords; vehicle speeding control and monitor, vehicle speed management, vehicle speeding enforcement, and combined through the system, method, road safety, accident prevention, control, and monitor. The search was done using search engines using Science Direct, Elsevier, google scholar, scientific research, Springer, ResearchGate, Ovid Medline, Scopus, PubMed, and ProQuest databases. An open search through google was equally done. References of the selected articles were reviewed to maximize the rate of articles finding. The inclusion criteria were: publications in peer-reviewed journals, in English, and with a focus on excessive speed monitoring and control for accident prevention, and qualitative studies were excluded from the review.

Articles were first screened reviewing their titles to exclude non-relevant articles. Then the abstract and full texts of the retained articles were reviewed. Endnote X9 software was used for organizing, title and abstract reviewing, and also identification of duplications. A PRISMA flow chart was used to extract the data from the included articles [9].

\section{Retrieved Contents}

A total of 658 studies were identified through electronic search engines. Duplicates of 458 were excluded and 200 were screened. A total of 61 and 40 articles were screened from the abstracts and full Pdf texts respectively. Finally, 15 relevant studies were included in the study. The retrieved contents are presented in the PRISMA flowchart of Figure 2.

\section{Results and Discussion}

Traffic planners and law enforcement agencies all over the world are paying much attention to road traffic monitoring systems and methods to improve road 


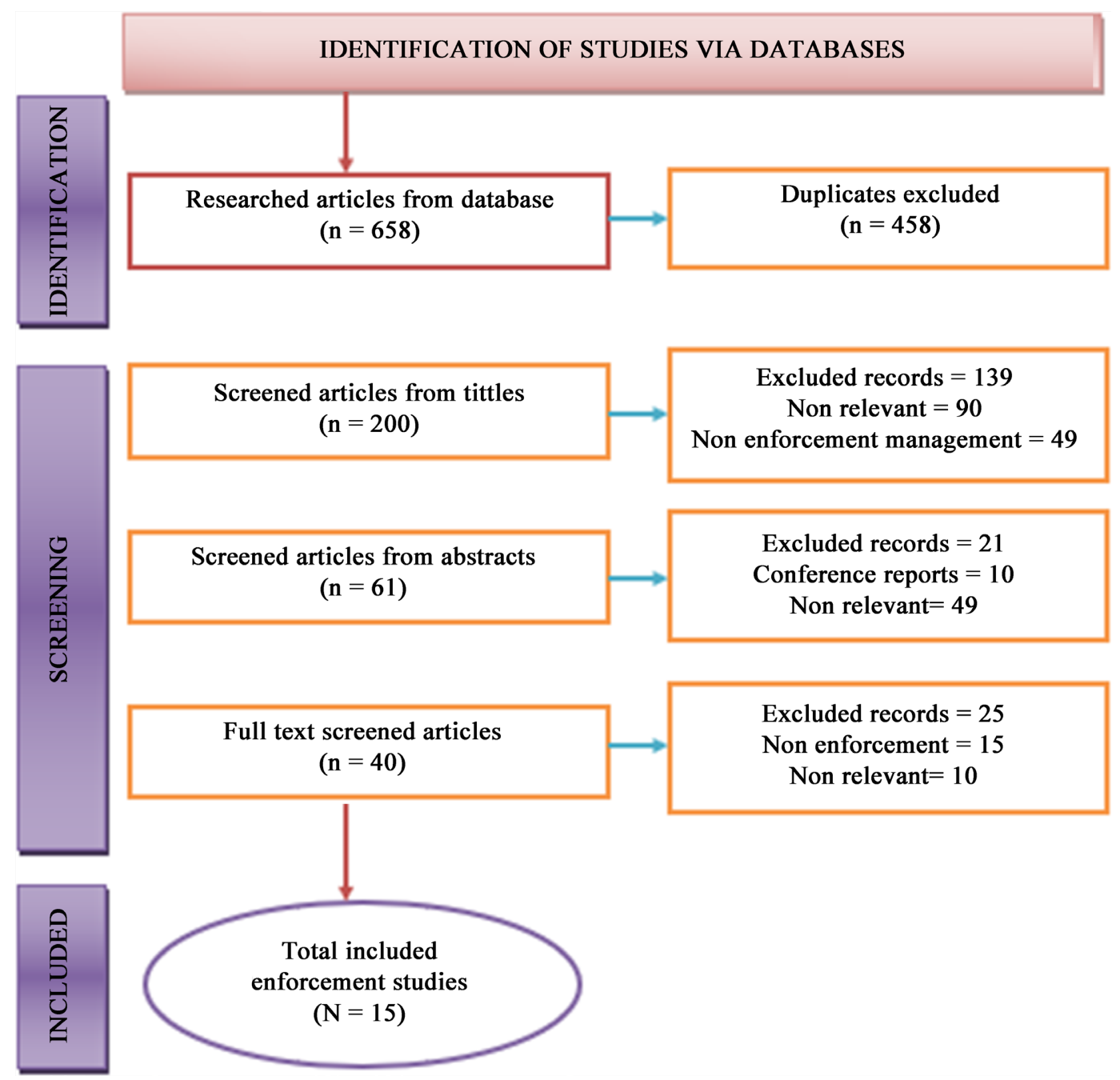

Figure 2. Prisma flow chart of systematic review.

safety policy, incident management, and road traffic reporting. In general, these monitoring systems are involved in counting, classifying, and or estimating the speeds of the moving vehicles on the road. To improve road safety, it is important to know about existing road traffic monitoring and control systems. Although speed camera is commonly used for road traffic monitoring, a variety of sensors have been employed for automatically monitoring and controlling the speed of vehicles [10].

Various strategies have so far been used for speed management (controlling and monitoring) including traditional methods such as advisory speed posting, speed limits, and road design as well as modern methods such as intelligent speed adaptation, safety cameras, support via an active accelerator pedal, and other strategies [11] and [12]. Furthermore, most developing countries use enforcement methods by sanctioning defaulters through billing and reporting.

Our review is limited to enforcement methods that have to do with sanctioning defaulters, billing and reporting of vehicle-based and road-based monitoring systems. Reviewing the different existing methods will permit us to identify their 
different limitations as well as the gap between the existing systems and ours. In the end, we shall produce a summary of included studies.

\subsection{Vehicle-Based Monitoring Systems}

In other words, called in-vehicle monitoring system (IVMS) consists of an electronic device or number of devices is installed in a vehicle to monitor driver activities and help identify behaviors such as excessive speed, harsh braking, rapid acceleration, or drowsy driving. The information is analyzed to evaluate the driver's safety and driving practices. [13] carried out a survey of recent vision-based on-road vehicle detection systems in a literature review.

One of the earliest IVMS developed was the use of microcontrollers to warn and detect the excess speed of violators. When a vehicle on speed approaches the speed limit, it displays the warning and if it exceeds the limit, the microcontroller records the violated speed and time. The LCDs the lane speed limit and shows the number of times, speed was violated. A GSM module sends ma messages to the nearest traffic personnel immediately after a violation occurs [13]. The system was later enforced by sending messages to violators and fines for payment [14]. Later a Zigbee transmitter was used to send the speed limit of the particular road lane and the speed of the vehicle is compared with the speed limit, and if it's exceeded then, the user within time limit should control it. If the time is out still the speed is not controlled manually by the driver, then the system itself will control the speed of the vehicle automatically [15]. A speed sensor was equally mounted on the flywheel of the car to detect excess speed, if over speeding occurs, the camera and the Raspberry PI extract the license plate number and send it immediately to the nearest concerned traffic authorities by means of GSM/GPRS. Once the details are updated, the driver is charged for over speeding [16]. The disadvantage of these systems is that the enforcements were limited in billing defaulters manually.

The first invention of automatic enforcement of billing was the use of a speed limiter which does not automatically limit the speed at which a vehicle moves but gives vocal warnings to drivers while approaching the speed limit. Failure to slow down triggers the speed limiter's reporting system and the driver is automatically sent a ticket for fine payments [17]. Speed control and accident alert system were developed to assist in road safety issues, whenever an accident happens, the system will identify and confirm it with the driver, it informs nearby ambulance. Also, it provides an alert whenever the driver exceeds the speed limit through GPS or Bluetooth. An accelerometer is installed on the flywheel of the vehicle with a camera that snaps and the driver is alert through a microcontroller in case of overspeeding [18].

So far it was noticed that the most developed IVMS enforcement method is limited to automatically informing excessive speed violators for fine payments. The main drawback of these systems is that they are very costly and can easily be handicapped by car owners if control wireless control measures are not put in place. 


\subsection{Road-Based Speed Monitoring Systems}

One of the first methods used for controlling and enforcing excessive speed on roads was using a speed detection device to measure the speed of each incoming vehicle with a double loop or piezo sensors and feed the data to the processing unit. When the measured speed exceeds the predetermined threshold value, the digital camera captures the image of the vehicle and the driver. An infringement notification paper is automatically printed out and then mailed to the registered owner of the vehicle [19]. The use of a point-to-point system has been commonly used. With this system, the time taken by the vehicle to travel from one set point to the other is calculated by a control circuit and displayed that on seven-segment displays. Moreover, if the vehicle crosses the speed limit, a buzzer sounds alerting the police [20]. Since the buzzer sound was not audible enough, the system was further developed by introducing a more abuzz alarm system [21]. Another improvement of the system was the use of GPS coordinates to calculate the speed of the vehicle with the maximum allowable speed in that area. If overspeeding is detected, a buzzer sound is generated from an active buzzer and alerts the driver that he is exceeding the speed limit. If the driver does not drive within the speed limit, an SMS is sent to traffic authorities and a ticket can be issued against the same vehicle [22]. A model was also developed that uses Arduino and IR sensors so that it alerts the over the speed of vehicles. The system accumulates information of vehicle by displaying on the LCD and if over-speed occurs it alerts by giving buzzer [23]. In addition to this model, GMS and RFID reader is used to pay defaulters fines automatically from their accounts [24]. The difference in enforcement here is that the defaulter is warned before being sanctioned. The system was limited in alerting drivers of excessive speed to slow down. The latter was a Highway Security Camera Systems (HSCS) that uses the live video streams of a surveillance camera, which gives the lateral view of the traffic and estimates the speed of the vehicles passing by with the help of image processing techniques. In case of excess speed, the image of the car is captured and the defaulter is notified through an SMS via a GSM module, and an snap shot of the vehicle is sent as an e-mail attachment [25]. This improvement was good but as regard enforcement, it was limited to notifying the control agents for further sanctions which were selective.

The most recently used system in African countries to control excessive speed on the highway is the Doppler Effect of speed gun which calculates the speed of the vehicle. If the detected speed is greater than a set speed threshold, a camera automatically captures the snap of the vehicle, and the license plate number is extracted using Digital Image Processing (DIP) techniques. A fine is collected and the information of the defaulter is stored in a database [26] and [27]. The archiving of offenders' information was a great improvement in the enforcement of speeding because it gives the records of offenders and permits a better sensitization to the road users but the sanction measures are slow and thus less effec- 
tive.

After discussing the results of vehicle-based and road-based control systems of speeding, it reveals that it is updated, developed, and implemented enforcement is limited to billing defaulters automatically and manually through SMS or email and informing control agents for necessary sanctions.

\section{Conclusion and Perspectives}

After a vivid examination of 15 studies on-road and vehicle-based systems as summarized on the extraction (Table 1), a critical analysis of the available literature

Table 1. Extraction table of included studies.

\begin{tabular}{|c|c|c|c|c|c|}
\hline Author & Country & Speed control method & Type & Material used & Enforcement's limitations \\
\hline [19] & China & $\begin{array}{l}\text { When the vehicle exceeds the speed } \\
\text { limit, a digital camera captures the } \\
\text { image of the vehicle. }\end{array}$ & Road-based & $\begin{array}{l}\text { Speed camera, GPS and } \\
\text { GMS }\end{array}$ & $\begin{array}{l}\text { A notification paper is } \\
\text { automatically sent to } \\
\text { defaulters for sanction } \\
\text { measures. }\end{array}$ \\
\hline [28] & India & $\begin{array}{l}\text { The violated vehicle receives a } \\
\text { message from the Zigbee transmitter } \\
\text { through microcontroller. }\end{array}$ & Vehicle-based & $\begin{array}{l}\text { Zigbee transmitter and } \\
\text { receiver, } \\
\text { microcontroller, LCD } \\
\text { and GMS }\end{array}$ & $\begin{array}{l}\text { GMS transmits Messages to } \\
\text { repeated violators for } \\
\text { payment at the tore gates. }\end{array}$ \\
\hline [15] & Bengaluru & $\begin{array}{l}\text { ZigBee is used with road signs to } \\
\text { automatically warn offender, then } \\
\text { the system itself will control the } \\
\text { speed of the vehicle automatically. }\end{array}$ & Vehicle-based & $\begin{array}{l}\text { Transmitter, Receiver } \\
\text { Zigbee receiver, LCD, } \\
\text { Dipole antenna } \\
\text { microcontroller) }\end{array}$ & $\begin{array}{l}\text { The speed of the car is } \\
\text { controlled automatically if } \\
\text { the driver persists at } \\
\text { excessive speed. }\end{array}$ \\
\hline [27] & Pakistan & $\begin{array}{l}\text { Speed camera automatically detects } \\
\text { over-speeding vehicles, extract the } \\
\text { license number of the vehicle and } \\
\text { send it via email to Toll Plaza. }\end{array}$ & Road-based & $\begin{array}{l}\text { Speed camera Modules } \\
\text { transmitter and receiver, } \\
\text { MATLAB }\end{array}$ & $\begin{array}{l}\text { Messages of violators are } \\
\text { sent to a Tollgate for } \\
\text { sanctions. }\end{array}$ \\
\hline [25] & India & $\begin{array}{l}\text { In case of over-speeding, the image } \\
\text { of the car is captured through a live } \\
\text { video stream of a surveillance } \\
\text { camera. }\end{array}$ & Road-based & $\begin{array}{l}\text { Video Camera and GSM } \\
\text { module }\end{array}$ & $\begin{array}{l}\text { The violator is notified } \\
\text { through an SMS and an } \\
\text { image of the vehicle is sent } \\
\text { as an e-mail attachment. }\end{array}$ \\
\hline [26] & India & $\begin{array}{l}\text { If the detected speed is greater than } \\
\text { the set speed threshold, the vehicle } \\
\text { and license plate number are } \\
\text { automatically snapped. }\end{array}$ & Road-based & $\begin{array}{l}\text { RF-section, transmitter } \\
\text { and received Digital } \\
\text { Image processing (DIP), } \\
\text { MATLAB }\end{array}$ & $\begin{array}{l}\text { Violators pay fines shortly } \\
\text { ahead to the toll gate and } \\
\text { their information is served } \\
\text { in a database. }\end{array}$ \\
\hline [20] & India & $\begin{array}{l}\text { The time taken by the vehicle to } \\
\text { travel from one set point to the } \\
\text { other is calculated. if the vehicle } \\
\text { crosses the speed limit, a buzzer } \\
\text { sounds alerting the police. }\end{array}$ & Road-based & $\begin{array}{l}\text { Infrared (IR) } \\
\text { transmitter, an IR } \\
\text { receiver, a control } \\
\text { circuit, and seven digital } \\
\text { segment displays }\end{array}$ & $\begin{array}{l}\text { The police in defaulters on } \\
\text { the spot for charges. }\end{array}$ \\
\hline [23] & & $\begin{array}{l}\text { The system accumulates } \\
\text { information of vehicle speed and if } \\
\text { over-speed occurs it alerts by giving } \\
\text { a buzzer. }\end{array}$ & Road-based & $\begin{array}{l}\text { I transmitter, receiver, } \\
\text { control unit, a buzzer } \\
\text { and an LCD }\end{array}$ & $\begin{array}{l}\text { SMS messages are sent to } \\
\text { defaulters through SMS for } \\
\text { sanctions. }\end{array}$ \\
\hline
\end{tabular}




\section{Continued}

\begin{tabular}{|c|c|c|c|c|c|}
\hline [21] & India & $\begin{array}{l}\text { Developed the previous system [20] } \\
\text { by introducing an alarm system. }\end{array}$ & Road-based & $\begin{array}{l}\text { IR transmitter/receiver, } \\
\text { an alarm, and a buzzer }\end{array}$ & $\begin{array}{l}\text { The police interrupts } \\
\text { defaulters on the spot for } \\
\text { charges. }\end{array}$ \\
\hline [14] & India & $\begin{array}{l}\text { A speed sensor is connected to a } \\
\text { microcontroller which detects when } \\
\text { the critical speed is exceeded. }\end{array}$ & Vehicle-based & $\begin{array}{l}\text { RF, GSM, speed sensor, } \\
\text { microcontroller, and a } \\
\text { computer }\end{array}$ & $\begin{array}{l}\text { A violation SMS is sent to } \\
\text { violators and the fine they } \\
\text { are supposed to pay. }\end{array}$ \\
\hline [18] & India & $\begin{array}{l}\text { In an ambulance management } \\
\text { system, the driver exceeds the speed } \\
\text { limit a speed camera sensor snap. }\end{array}$ & Vehicle-based & $\begin{array}{l}\text { GPS, Bluetooth, } \\
\text { Microcontroller, camera } \\
\text { sensor }\end{array}$ & $\begin{array}{l}\text { An alert message is sent to } \\
\text { the driver and equally } \\
\text { stored in a database. }\end{array}$ \\
\hline [17] & Nigeria & $\begin{array}{l}\text { A vocal warning is given to drivers } \\
\text { who exceeds speed limit. Failure to } \\
\text { slow triggers reporting system. }\end{array}$ & Vehicle-based & $\begin{array}{l}\text { Speed limiter, controller, } \\
\text { camera, GSM/GPRS }\end{array}$ & $\begin{array}{l}\text { The violator is automatically } \\
\text { ticketed by the SMS from } \\
\text { the reporting system. }\end{array}$ \\
\hline [22] & India & $\begin{array}{l}\text { GPS coordinates are used to locate } \\
\text { excessive speed. If detected, a buzzer } \\
\text { sound alerts map offender. }\end{array}$ & Road-based & $\begin{array}{l}\text { Technology (GPS), } \\
\text { buzzer, controller }\end{array}$ & $\begin{array}{l}\text { An over-speed ticket is } \\
\text { issued against the violated } \\
\text { vehicle. }\end{array}$ \\
\hline [16] & India & $\begin{array}{l}\text { The speed sensor on the flywheel of } \\
\text { the car snaps, if over speeding } \\
\text { occurs. }\end{array}$ & Vehicle-based & $\begin{array}{l}\text { Speed Sensor, Module, } \\
\text { Arduino Mega, and a } \\
\text { Raspberry Pi }\end{array}$ & $\begin{array}{l}\text { The system generates } \\
\text { messages of violators and } \\
\text { informs the nearest } \\
\text { authorities of charges. }\end{array}$ \\
\hline [24] & America & $\begin{array}{l}\text { With a unique account to every } \\
\text { vehicle fine payment, offenders of } \\
\text { excessive speed pay fines } \\
\text { automatically. }\end{array}$ & Road-based & $\begin{array}{l}\text { Arduino Mega, GSM } \\
\text { module, RFID reader } \\
\text { (EM18), IR Sensor }\end{array}$ & $\begin{array}{l}\text { An alert message is } \\
\text { generated for administrative } \\
\text { proceedings. }\end{array}$ \\
\hline
\end{tabular}

reveals that there are several shortcomings of the existing enforcement methods on vehicle speed control and monitoring approaches. Some of the existing vehicle speed monitoring systems have high equipment costs, complex installation processes, exposure to corruption, high maintenance cost, and dependency on weather conditions. Some systems have difficulties in managing collected data while others are limited to billing defaulters through sanction messages. The difficulties faced are that it is cumbersome to access and further processing is sanction messages to defaulters of the prevailing models. The literature review also shows that no speed enforcement system is available that uses website SMS to suspend delinquent defaulted vehicles from circulating. The flexibility of the speed enforcement approach models is an important issue in this regard. To obviate the shortcomings of the existing reviews of speed control and monitoring enforcement systems, we intend to fill the gap by designing a prototype network model that can automatically sanction defaulters of speeding through the payment of fines within seventy-two hours and suspend delinquent defaulters from circulating till the situation is regularized. Our stand on innovation is limited to "automated web-based and SMS sanction of delinquent defaulters of excessive speed on Cameroon highways and at large. 


\section{Acknowledgements}

We wish to appreciate the supervisor and the co-supervisor Prof NDOH MBUE Innocent and Dr. AYISSI Zacharie Merlin respectively for their wonderful assistance to see us through this research work. Our endless appreciations also go to the doctorate student, AWA Terence ACHIRI for proofreading the work.

\section{Conflicts of Interest}

The authors declare no conflicts of interest regarding the publication of this paper.

\section{References}

[1] Ameratunga, S., Hijar, M. and Norton, R. (2006) Road-Traffic Injuries: Confronting Disparities to Address a Global-Health Problem. Lancet, 367, 1533-1540. https://doi.org/10.1016/S0140-6736(06)68654-6

[2] Sundar Kumar, P., Viswanadham, V. and Bharathi, B. (2019) Analysis of Road Accidents. IOP Conference Series. Materials Science and Engineering, 590, Article ID: 012029. https://doi.org/10.1088/1757-899X/590/1/012029

[3] Deme, D. (2019) Review on Factors Causes Road Traffic Accident in Africa. Journal of Architecture and Construction, 2, 41-49. https://www.researchgate.net/publication/338232368

[4] Zogo Tsala, S.A., Ayissi, M.Z., Azeh, G., Noah, P.A., Betene Ebanda, F. and Ayina Ohandja, L.M. (2021) An In-Depth Analysis of the Causes of Road Accidents in Developing Countries: Case Study of Douala-Dschang Highway in Cameroon. Journal of Transportation Technologies, 11, 455-470.

https://doi.org/10.4236/jtts.2021.113030

[5] Sobngwi-Tambekou, J., Bhatti, J., Kounga, G., Salmi, L.R. and Lagarde, E. (2010) Road Traffic Crashes on the Yaoundé-Douala Road Section, Cameroon. Accident Analysis and Prevention, 42, 422-426. https://doi.org/10.1016/j.aap.2009.09.003

[6] Elvik, R. (2012) Speed Limits, Enforcement, and Health Consequences. Annual Review of Public Health, 33, 225-238.

https://doi.org/10.1146/annurev-publhealth-031811-124634

[7] Madjadoumbaye, J., Fokwa, D., Gilbert, T., Ngopnang, R.B.P.B. and Tchewou, T.T.T. (2012) Critical Analysis of Speed Bumps: Case Study of the Triangle Yaoundé-DoualaBafoussam-Yaoundé Highway in Cameroon. International Journal of Emerging Technology and Advanced Engineering, 2, 457-463.

https://www.researchgate.net/publication/285101316

[8] Ahsan, M. (2014) Development of a Prototype Wireless Vehicle Speed Monitoring System. Master of Engineering Masters, Mechanical and Manufacturing Engineering, Dublin City University, Dublin.

[9] Slikboer, R., Muir, S.D., Silva, S.S.M. and Meyer, D. (2020) A Systematic Review of Statistical Models and Outcomes of Predicting Fatal and Serious Injury Crashes from Driver Crash and Offense History Data. Systematic Reviews, 9, Article No. 220. https://doi.org/10.1186/s13643-020-01475-7

[10] Arnold, D., Dougall, Jr., J.B., Giles, B.C., Karlinsey, T.W. and Waite, J.L. (2008) Systems and Methods for Monitoring Speed. US Patent No. US 7,426,450 B2.

[11] Jaarsma, R., Louwerse, R., Dijkstra, A., de Vries, J. and Spaas, J.-P. (2011) Making Minor Rural Road Networks Safer: The Effects of $60 \mathrm{~km} / \mathrm{h}$-Zones. Accident Analy- 
sis \& Prevention, 43, 1508-1515. https://doi.org/10.1016/j.aap.2011.03.001

[12] Kweon, Y.-J. and Oh, C. (2011) Identifying Promising Highway Segments for Safety Improvement through Speed Management. Transportation Research Record, 2213, 46-52. https://doi.org/10.3141/2213-07

[13] Sun, Z., Bebis, G. and Miller, R. (2006) On-Road Vehicle Detection: A Review. IEEE Transactions on Pattern Analysis and Machine Intelligence, 28, 694-711. https://doi.org/10.1109/TPAMI.2006.104

[14] Vijin, P., Basheer, V.S., Shaab Mon, P.K., Sabin, M.K., Nikhil, V. and Nisi, K. (2015) Advanced Vehicle Over Speed Detection and Billing System (AVODABS). 2015 Online International Conference on Green Engineering and Technologies, Coimbatore, 27 November 2015, 1-6. https://doi.org/10.1109/GET.2015.7453808

[15] Amarnarayan, Saikumar, C., Mohan, C., Ajaykumar and Sridhar, N. (2016) Automatic Over speed Controlling of Vehicle. International Journal of Combined Research \& Development (IJCRD), 5, 706-709.

[16] Deshpande, S., Bhole, V., Dudhade, P., Gourka, N. and Darade, S. (2017) Implementing a System to Detect over Speeding \& Inform Authorities in Case of Any Violations. International Research Journal of Engineering and Technology, 4, 2445-2449. http://www.irjet.net

[17] Matthews, V.O., Noma-Osaghae, E. and Uzairue Idiake, S. (2018) An Intelligent In-Vehicle Wireless Multilingual Over-Speed Announcer and Reporter. International Research Journal of Engineering and Technology (IRJET), 5, 285-288.

[18] Suganthi, D., Kamesh Aravind, P. and Sarin Raj, P.K. (2020) Monitoring the Over Speed of Vehicle and Ambulance Management with Arduino Sensor on Android Platform. International Journal of Engineering Science and Computing, 8, 16984-16988. http://ijesc.org/

[19] Kang, J.-G. (2002) Changes of Speed and Safety by Automated Speed Enforcement Systems. IATSS Research, 26, 38-44. https://doi.org/10.1016/S0386-1112(14)60041-8

[20] Jain, M., Kumar, P., Singh, P., Arora, C. and Sharma, A. (2015). Detection of Over Speeding Vehicles on Highways. (2015) Detection of Over-Speeding Vehicles on Highways. International Journal of Computer Science and Mobile Computing, 4, 613-619. http://www.ijcsmc.com

[21] GufranHaseeb, M., Kumar, A., Kumar Horo, S. and Tiwary, A. (2018) Highway Overspeed Detecter and Alarming System. International Journal of Engineering Science and Computing, 8, 16287-16291. http://ijesc.org/

[22] Kodali, R.K. and Sairam, M. (2016) Over Speed Monitoring System. 2016 2nd International Conference on Contemporary Computing and Informatics, Greater Noida, 14-17 December 2016, 752-757. https://doi.org/10.1109/IC3I.2016.7918061

[23] Vutturi, M., Palle, S. and Bonala, S. (2020) Automatic Speed Detection and Reporting System Using Arduino. International Journal of Scientific Engineering and Research, 8, Paper ID: 14012002.

[24] Sriram Adithya, V., Sri Sowmya, S., Vamsi Krishna, R., Raghavendra, S.G.S. and Rama Krishna, Y. (2020) Vehicle Speed Monitoring. International Journal of Scientific Research in Engineering and Management, 4, 1-4. https://www.researchgate.net/publication/345709698

[25] Upadhyaya, V. and Shaikh, S.H. (2016) Vehicle Speed Detection and Notification for Highway Monitoring. Information-An International Interdisciplinary Journal, 19, 4169-4176.

[26] Sawant, A.R., Ikke, V., Khandale, J. and Chavan, N. (2016) Car Over-Speed Detec- 
tion with Remote Alerting. International Journal for Innovative Research in Science \& Technology, 2, 273-277.

[27] Malik, S.M., Iqbal, M.A., Hassan, Z., Tauqeer, T., Hafiz, R. and Nasir, U. (2014) Automated Over Speeding Detection and Reporting System. 2014 16th International Power Electronics and Motion Control Conference and Exposition, Antalya, 21-24 September 2014, 1104-1109. https://doi.org/10.1109/EPEPEMC.2014.6980657

[28] Rubini, R. and Uma Makeswari, A. (2013) Over Speed Violation Management of a Vehicle through Zigbee. International Journal of Engineering and Technology, 5, 340-344. 